\title{
Multiproxy summer and winter surface air temperature field reconstructions for southern South America covering the past centuries
}

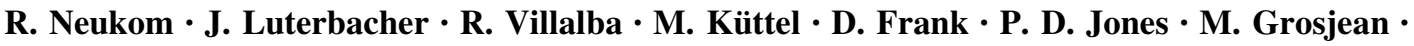 \\ H. Wanner · J.-C. Aravena $\cdot$ D. E. Black $\cdot$ D. A. Christie $\cdot$ R. D'Arrigo $\cdot$ A. Lara \\ M. Morales • C. Soliz-Gamboa $\cdot$ A. Srur $\cdot$ R. Urrutia $\cdot$ L. von Gunten
}

Received: 12 November 2009/ Accepted: 8 March 2010/Published online: 28 March 2010

(C) Springer-Verlag 2010

\begin{abstract}
We statistically reconstruct austral summer (winter) surface air temperature fields back to $\mathrm{AD} 900$ (1706) using 22 (20) annually resolved predictors from natural and human archives from southern South America
\end{abstract}

Electronic supplementary material The online version of this article (doi:10.1007/s00382-010-0793-3) contains supplementary material, which is available to authorized users.

R. Neukom $(\bowtie) \cdot$ M. Küttel · M. Grosjean · H. Wanner ·

L. von Gunten

Oeschger Centre for Climate Change Research (OCCR),

University of Bern, Bern, Switzerland

e-mail: neukom@giub.unibe.ch

R. Neukom · M. Küttel · M. Grosjean · H. Wanner ·

L. von Gunten

Institute of Geography, Climatology and Meteorology,

University of Bern, Bern, Switzerland

\section{J. Luterbacher}

Department of Geography; Climatology, Climate Dynamics and Climate Change, Justus Liebig University of Giessen,

Giessen, Germany

R. Villalba $\cdot$ M. Morales $\cdot$ A. Srur

Instituto Argentino de Nivología, Glaciología y Ciencias

Ambientales (IANIGLA), CONICET, Mendoza, Argentina

\section{Küttel}

Department of Earth and Space Sciences,

University of Washington, Seattle, USA

D. Frank

Swiss Federal Research Institute WSL,

8903 Birmensdorf, Switzerland

P. D. Jones

Climatic Research Unit, School of Environmental Sciences,

University of East Anglia, Norwich, UK
(SSA). This represents the first regional-scale climate field reconstruction for parts of the Southern Hemisphere at this high temporal resolution. We apply three different reconstruction techniques: multivariate principal component regression, composite plus scaling, and regularized expectation maximization. There is generally good

\author{
J.-C. Aravena \\ Centro de Estudios Cuaternarios de Fuego Patagonia y Antártica \\ (CEQUA), Avenida Bulnes 01890, Punta Arenas, Chile \\ D. E. Black \\ School of Marine and Atmospheric Sciences, Stony Brook \\ University, Stony Brook, USA \\ D. A. Christie · A. Lara · R. Urrutia \\ Laboratorio de Dendrocronología, Facultad de Ciencias \\ Forestales y Recursos Naturales, Universidad Austral de Chile \\ Valdivia, Casilla 567, Valdivia, Chile \\ R. D'Arrigo \\ Tree-Ring Laboratory, Lamont-Doherty Earth Observatory, \\ Earth Institute at Columbia University, Palisades, NY, USA
}

A. Lara

Núcleo Científico Milenio FORECOS,

Fundación FORECOS, Valdivia, Chile

C. Soliz-Gamboa

Section of Ecology and Biodiversity, Faculty of Science,

Institute of Environmental Biology, Utrecht University,

P.O. Box 80084, 3508 TB Utrecht, The Netherlands

L. von Gunten

Department of Geosciences, Climate System Research Center,

University of Massachusetts, Amherst, USA 
agreement between the results of the three methods on interannual and decadal timescales. The field reconstructions allow us to describe differences and similarities in the temperature evolution of different sub-regions of SSA. The reconstructed SSA mean summer temperatures between 900 and 1350 are mostly above the 1901-1995 climatology. After 1350, we reconstruct a sharp transition to colder conditions, which last until approximately 1700 . The summers in the eighteenth century are relatively warm with a subsequent cold relapse peaking around 1850. In the twentieth century, summer temperatures reach conditions similar to earlier warm periods. The winter temperatures in the eighteenth and nineteenth centuries were mostly below the twentieth century average. The uncertainties of our reconstructions are generally largest in the eastern lowlands of SSA, where the coverage with proxy data is poorest. Verifications with independent summer temperature proxies and instrumental measurements suggest that the interannual and multi-decadal variations of SSA temperatures are well captured by our reconstructions. This new dataset can be used for data/model comparison and data assimilation as well as for detection and attribution studies at sub-continental scales.

Keywords Climate change $\cdot$ Climate field reconstructions $\cdot$ Temperature $\cdot$ South America

\section{Introduction}

Understanding the current and future processes and dynamics of the climate system requires knowledge of the spatial patterns, trends, amplitudes and frequencies of climatic variations including information from the past (Jansen et al. 2007; Jones et al. 2009; Mann et al. 2008). While instrumental records (e.g. Brohan et al. 2006) provide insights into climate variability of the recent anthropogenically forced climate system, they are often too short to allow assessment of the natural modes of climatic variations. In this regard, proxy data-records which serve as a surrogate for instrumental measurements-have allowed climate variations to be evaluated over the past centuries to millennia (see e.g., Jones et al. 2009 for a review). Climate reconstructions provide insight into the mechanisms or forcings underlying observed climate variability and are of importance for data/climate model comparisons.

Until recently, the rather low number and uneven spatial distribution of temporally-highly-resolved proxies from the Southern Hemisphere (SH) did not allow reliable continental scale reconstructions to be developed at interannual to interdecadal time scales (Jansen et al. 2007; Mann and Jones 2003). Consequently, the few existing multi-proxy temperature reconstructions from the $\mathrm{SH}$ focus on the hemispheric mean (Jones et al. 1998; Mann and Jones 2003; Mann et al. 2008) and depend upon on a small number of SH proxies (see e.g., Ljungqvist 2009 and references therein). Accordingly, these reconstructions do not provide reliable representations of the spatial patterns, trends and amplitudes of regional to continental scale SH climate. However, reconstructions of high spatial and temporal resolution are important, because they illuminate key climatic features, such as regionally very hot/cool seasonal conditions that may be masked in a hemispheric reconstruction. The limited understanding of SH climate is particularly striking given the importance of understanding the potential see-saw mechanisms between the climatic state of the Northern Hemisphere $(\mathrm{NH})$ versus SH continents on interannual to millennial time scales as well as the crucial role of the SH oceans in regulating global climate variability (e.g., Busalacchi 2004).

South America is a key region for the understanding of Southern Hemisphere climate dynamics, as it is the only landmass that extends from the tropics to latitudes poleward of $50^{\circ} \mathrm{S}$. It is influenced by a variety of atmospheric and oceanic patterns, including globally relevant largescale modes such as the El Niño Southern Oscillation (ENSO), the Southern Annular Mode (SAM) and the Pacific Decadal Oscillation (PDO; Garreaud et al. 2009). Furthermore, South America's climate is strongly affected and modulated by the continuous Cordillera of the Andes in the west and the large Amazon basin in the northeast.

Due to the still very limited number of highly resolved paleoclimatic records from the tropical part of South America (Villalba et al. 2009), this study focuses on southern South America (SSA, south of $20^{\circ} \mathrm{S}$ ).

The largest fraction of the published paleoclimatic information from SSA is represented by Andean tree rings (see Boninsegna et al. 2009 for a review). Annually resolved temperature reconstructions on local to regional scale have been developed using tree rings from southern Patagonia and Tierra del Fuego back to 1650 (Aravena et al. 2002; Boninsegna et al. 1989; Villalba et al. 2003) as well as from northern Patagonia, where the longest tree ring records extend back more than 3,500 years (Lara and Villalba 1993; Villalba 1990; Villalba et al. 1997a, 2003). New records from ice cores (Vimeux et al. 2009 and references therein) and lake sediments (e.g. von Gunten et al. 2009) complement the network of temporally highly resolved natural proxies from SSA. The regional temperature history of the subtropical Andes has been investigated based on the lake sediment record from Laguna Aculeo (von Gunten et al. 2009), covering the period 857-2003. In addition to the natural proxies, several documentary records are available, most of them originating from subtropical SSA (e.g. Neukom et al. 2009; Prieto and García 
Herrera 2009). Along with proxies from outside SSA, that are connected to the South American climate via teleconnections, the data now allow us to establish an extensive set of climate predictors for past SSA climate. On centennial timescales, glacier length records from the Andes also provide insight into the climate history of SSA (Koch and Kilian 2005; Luckman and Villalba 2001; Masiokas et al. 2009; Villalba 1994).

In this work, we present the first SSA austral summer (DJF) and winter (JJA) temperature field reconstructions. Out of an extended set of 144 annually resolved SSA climate proxies we select 22 (20) predictors for the summer (winter) reconstructions. Three different techniques were applied to statistically reconstruct the SSA mean as well as spatial temperature fields. Proxy data were sufficient to reconstruct winter temperatures back to 1706 and summer temperatures back to 900 .

\section{Data and methods}

\subsection{Instrumental calibration data}

We used the new monthly and $0.5^{\circ} \times 0.5^{\circ}$ resolved CRU TS 3 temperature grid covering 1901-2006 (updated from Mitchell and Jones 2005) as a predictand for the reconstructions (see Sect. 2.3 for methodological details). Seasonal values were calculated by averaging the austral summer (December to February, DJF) and winter (June to August, JJA) months, respectively. We selected this traditional definition of the seasons, because the combination of these months represents a compromise with respect to the varying temperature sensitivities of the different proxy records. We defined the reconstruction area (SSA) as the terrestrial area between $20^{\circ} \mathrm{S}$ and $55^{\circ} \mathrm{S}$ and between $30^{\circ} \mathrm{W}$ and $80^{\circ} \mathrm{W}$, covered by a total of 2,358 (land-) grid boxes.

\subsection{Predictor data}

As a basis for the proxy evaluation and temperature reconstruction, we compiled 144 proxies, which are sensitive to SSA climate (Tables S1-S3 in the supplementary material). The dataset includes records from natural archives (tree rings, lake and marine sediments, ice cores and corals), documentary evidence and a set of homogenized instrumental temperature measurements. Some of the records were additionally processed as described in the supplementary material. Due to the limited number of long proxies from SSA, we also included records from distant areas into our predictor sets. Earlier studies based on instrumental measurements (e. g. Dettinger et al. 2001; Garreaud and Battisti 1999; Garreaud et al. 2009; Villalba et al. 1997b) revealed that these regions are related to SSA climate via teleconnections, mainly SAM and ENSO, and can explain significant fractions of SSA summer and winter temperature variability. Together, ENSO and SAM explain $38 \%$ of annual SSA mean temperature variability 19502006. The spatial correlations of SSA summer and winter temperatures with ENSO and SAM are shown in Fig. S1 in the supplementary material. However, we are aware that the inclusion of the proxies from distant areas may bias the reconstruction results, because the teleconnections patterns relating them to SSA climate may not be stable through time. Recent studies from Europe showed that the quality and location of predictors is probably more important for reliable reconstructions than the total number of predictors (Küttel et al. 2007; von Storch et al. 2009). Working in this direction, we assessed the quality and value of each proxy individually, finally reducing our predictor set to 22 (20) summer (winter) temperature proxies. As selection criteria we used the change in predictive skill of the predictor set within the verification period, when a candidate series is added to/removed from a previous set (detailed description of the procedure see supplementary material). An overview of the finally selected records and their temporal span is provided in Tables 1 and 2 and Fig. 1. The optimized set for summer consists of 16 records from within SSA (data sources see Table 1): 11 tree ring chronologies, mainly from the Patagonian Andes, a lake sediment record from central Chile, and 4 long instrumental temperature time series. The set is completed by six proxies from outside SSA: a marine sediment record from the Cariaco Basin off Venezuela, $\delta^{18} \mathrm{O}$ and accumulation series from the Quelccaya ice core, a tree ring based temperature reconstruction from New Zealand, and two coral records from Australian coastal waters. For the winter temperature reconstructions, the optimized proxy set (data sources see Table 2) contains four tree ring, two documentary, and three instrumental records from within SSA. Proxy data from outside SSA include: a tree ring record from the Bolivian Altiplano, a documentary ENSO index from Peru, three grid cells of $\mathrm{v}$ wind vectors from the CLIWOC/ICOADS database, two coral records from the tropical Pacific, a SOI reconstruction based on tree rings from Indonesia and southwestern North America, a coral and tree ring based PDSI reconstruction from Java, and two Antarctic ice cores. Tables 1 and 2 show that the selected predictor series have different ending years. Therefore, there is a trade-off between maximizing the length of the overlap period with the instrumental target and minimizing the number of missing values in the predictor matrix. We find the period 19011995 a compromise with $5.7 \%$ (5.6\%) missing values in the summer (winter) predictor matrix. Missing values in the predictor matrix of each season in this overlap period were filled in by applying an EOF (empirical orthogonal functions) based algorithm (Scherrer and Appenzeller 2006). 
Table 1 Predictors used for the summer temperature reconstructions

\begin{tabular}{|c|c|c|c|c|}
\hline Name & Archive & Start & End & Reference \\
\hline Quelccaya accumulation & Ice core & 488 & 2003 & Thompson et al. $(2000,2006)$ \\
\hline Quelccaya $\delta^{18} \mathrm{O}$ & Ice core & 488 & 2003 & Thompson et al. $(2000,2006)$ \\
\hline Laguna Aculeo pigments & Lake sediment & 857 & 2003 & von Gunten et al. (2009) \\
\hline New Zealand temperature reconstruction & Tree rings & 900 & 1999 & Cook et al. (2002) \\
\hline Cariaco Basin $\mathrm{Mg} / \mathrm{Ca}$ & Marine sediment & 1222 & 1990 & Black et al. (2007) \\
\hline Cluster CAN 11 & Tree rings & 1493 & 2002 & Lara et al. (2008) \\
\hline Santa Lucia & Tree rings & 1646 & 1986 & Szeicz et al. (2000) \\
\hline Cluster CAN 24 & Tree rings & 1677 & 2002 & Lamarche et al. (1979), Lara et al. (2008) \\
\hline Cluster CAN 4 & Tree rings & 1704 & 1994 & Lara et al. (2001), Schmelter (2000) \\
\hline Great Barrier Reef $\mathrm{Ba} / \mathrm{Ca} \mathrm{DJF}$ & Coral & 1758 & 1998 & McCulloch et al. (2003) \\
\hline Abrolhos $\delta^{13} \mathrm{C}$ Nov/Dec & Coral & 1794 & 1993 & Kuhnert et al. (1999) \\
\hline Glaciar Frias & Tree rings & 1802 & 1985 & Villalba et al. (1990) \\
\hline Cluster NWA 2 & Tree rings & 1818 & 2001 & Villalba et al. (1992), Morales et al. (2004) \\
\hline Cluster SAN 2 & Tree rings & 1845 & 1996 & Aravena et al. (2002) \\
\hline Cluster CAN 16 & Tree rings & 1845 & 1994 & Villalba et al. (1997a) \\
\hline Cluster CAN 19 & Tree rings & 1865 & 1998 & Lara et al. (2005) \\
\hline Cluster CAN 14 & Tree rings & 1869 & 1994 & Villalba et al. (1997a), Schmelter (2000) \\
\hline Vilches & Tree rings & 1880 & 1996 & Lara et al. (2001) \\
\hline Campinas DJF & Instrumental & 1890 & 2003 & Vargas and Naumann (2008) \\
\hline Tucuman DJF & Instrumental & 1891 & 2000 & Vargas and Naumann (2008) \\
\hline Corrientes DJF & Instrumental & 1894 & 2004 & Vargas and Naumann (2008) \\
\hline Rio Gallegos DJF & Instrumental & 1896 & 2004 & Vargas and Naumann (2008) \\
\hline
\end{tabular}

\subsection{Reconstruction methods}

Three different reconstruction methodologies were applied: multivariate principal component regression (PCR), composite-plus-scaling (CPS) and regularized expectation maximization (RegEM). In PCR (Küttel et al. 2009; Luterbacher et al. 2002, 2004, 2007; Riedwyl et al. 2009; Xoplaki et al. 2005) a transfer function between a fixed number of principal components of the predictor and predictand datasets is established for the calibration period using multivariate regression based on ordinary least squares. The resulting regression models are then used to estimate the temperatures of the reconstruction period assuming temporal stability and linearity of the relation between the predictor and the predictand. A major disadvantage of regression-based reconstructions is the fact that they may be biased by a systematic loss of variance leading to underestimations of past climate variations (e.g. von Storch et al. 2004). In order to minimize such reductions of variance back in time, the temperatures reconstructed by PCR were rescaled to the mean and standard deviation of the predictand in the calibration period (e.g. Cook et al. 2004). CPS avoids this loss of variability by simply scaling a composite of the predictor data against the predictand in the calibration period (e.g. Esper et al. 2005; Jones et al.
1998). We built the composites by calculating the weighted mean of the predictors. As weighting factors, we used the correlation coefficient of each predictor with the target in the calibration period. In order to take account of the changing number of predictors over time, a variance stabilization algorithm (Frank et al. 2007) was applied to the CPS results. RegEM (Mann et al. 2007, 2008, 2009; Riedwyl et al. 2008, 2009; Rutherford et al. 2005; Schneider 2001) iteratively imputes missing values in the combined predictor-predictand input matrix until a predefined convergence criterion is fulfilled. The regression parameters between the available proxy and instrumental variables are thereby computed based on the estimated mean and covariance of the input matrix. We performed the regularization of the EM algorithm, which is necessary to avoid overfitting in the regressions, using truncated total least squares (Mann et al. 2007; Riedwyl et al. 2008, 2009). For a general comparison and description of the three approaches we refer to Jones et al. (2009) and references therein.

As the number of available predictors changes over time, the reconstructions and verifications were repeatedly performed as each predictor entered or exited the available set of proxy data (18 combinations for summer and 41 for winter) for all the three reconstruction methods. 
Table 2 Predictors used for the winter temperature reconstructions

\begin{tabular}{|c|c|c|c|c|}
\hline Name & Archive & Start & End & Reference \\
\hline Talos deuterium & Ice core & 1217 & 1996 & Stenni et al. (2002) \\
\hline Peru El Niño index & Documentary & 1550 & 1990 & $\begin{array}{l}\text { García-Herrera et al. (2008), } \\
\text { 20th century data from Quinn and Neal (1992) }\end{array}$ \\
\hline Santiago de Chile precipitaion index & Documentary & 1540 & 2006 & Taulis (1934), Neukom et al. (2009) \\
\hline Urvina Bay $\delta^{18} \mathrm{O}$ & Coral & 1607 & 1981 & Dunbar et al. (1994) \\
\hline SOI reconstruction & Tree rings & 1706 & 1977 & Stahle et al. (1998) \\
\hline Cluster SAN 4 & Tree rings & 1724 & 1984 & Boninsegna et al. (1989) \\
\hline Rarotonga Sr/Ca SON & Coral & 1726 & 1996 & Linsley et al. (2000) \\
\hline CLIWOC/ICOADS v cell 626 JJA & Documentary/early instrumental & 1750 & 2002 & Garcia-Herrera et al. (2005), Küttel et al. (2009) \\
\hline CLIWOC/ICOADS v cell $671 \mathrm{JJA}$ & Documentary/early instrumental & 1750 & 2002 & Garcia-Herrera et al. (2005), Küttel et al. (2009) \\
\hline CLIWOC/ICOADS v cell 672 JJA & Documentary/early instrumental & 1750 & 2002 & Garcia-Herrera et al. (2005), Küttel et al. (2009) \\
\hline Monte Grande & Tree rings & 1761 & 1988 & ITRDB series arge 049 \\
\hline Java PDSI reconstruction & Tree rings/Coral & 1787 & 2003 & D'Arrigo et al. (2006) \\
\hline Law Dome $2000 \delta^{18} \mathrm{O}$ & Ice core & 1800 & 1999 & van Ommen et al. (2004) \\
\hline El Chalten Bajo & Tree rings & 1807 & 2003 & Srur et al. (2008) \\
\hline Cluster ALT 1 & Tree rings & 1860 & 1993 & Solíz et al. (2009 ) \\
\hline Central Andes snow days & Documentary & 1885 & 1996 & Prieto et al. $(2001 \mathrm{a}, \mathrm{b})$ \\
\hline Tucuman JJA & Instrumental & 1891 & 2000 & Vargas and Naumann (2008) \\
\hline Cluster CAN 17 & Tree rings & 1892 & 1994 & Villalba et al. (1997a), Schmelter (2000) \\
\hline Corrientes JJA & Instrumental & 1894 & 2004 & Vargas and Naumann (2008) \\
\hline Rio Gallegos JJA & Instrumental & 1896 & 2004 & Vargas and Naumann (2008) \\
\hline
\end{tabular}

Reconstructions and statistics were then aggregated to continuous time series in such a way that every time period is reconstructed by the maximum available number of predictors. We used all three methods to perform two different reconstructions: a reconstruction optimized for the analysis of the evolution of SSA mean temperatures (henceforth SSA mean reconstruction) and a reconstruction for the analysis of spatial features, such as regional differences in trends, amplitudes and uncertainties (spatial reconstruction). The predictor and predictand datasets as well as the general reconstruction procedures used for both the SSA mean and spatial reconstructions are the same, but with slightly different methodological settings (Table 3).

We tested different truncation thresholds for the number of principal components (PCs) of the predictor data used in PCR, finally retaining the first $n$ PCs explaining 85 (80) percent of variability in the predictor data for the SSA mean (spatial) reconstruction. This setting yielded the highest reconstruction skills (RE, $r^{2}$ ) for most of the evaluated predictor sets (not shown). For PCR and RegEM, the first $n$ PCs explaining 95\% of variability in the CRU TS 3 grid were used as predictand for both the SSA mean and spatial reconstructions. In the case of the SSA mean CPS reconstruction, we used the spatial average of the instrumental grid as predictand (i.e. we scaled the predictor composite to mean and standard deviation of this average series). The spatial CPS reconstruction was performed by building the composite separately for each grid cell and scaling it to the corresponding instrumental series (i.e. for each cell a separate CPS reconstruction was performed).

The quality of the instrumental grid is particularly low in some regions of SSA in the pre-1931 period, due to the sparse coverage of these areas with instrumental stations (Fig. S2, left panel; Garreaud et al. 2009). For example in Argentina, $45 \%$ of the currently available GHCN temperature station data (Peterson and Vose 1997) begin in 1931 and only $14 \%$ have data for the pre-1931 period. Nevertheless, the average over entire SSA is very likely to be reliable back to 1901 , because the grid cells, which are most representative for the SSA mean, are mostly within the area with high coverage of instrumental stations back to 1901 (Fig. S2). For the SSA mean reconstructions we, therefore, used the period 1901-1995 for calibration, whereas for the spatial reconstructions, we used a shorter calibration period (1931-1995) in order to obtain reliable reconstructions in all regions (Table 3 ).

\subsection{Reconstruction quality assessments}

The uncertainties (standard errors, SE) of the Gaussian filtered reconstructions were calculated as in Xoplaki et al. (2005) by using Gaussian white noise to make the verification residuals consistent (Briffa et al. 2002; Mann et al. 1998). Uncertainties were calculated for the SSA mean, as 


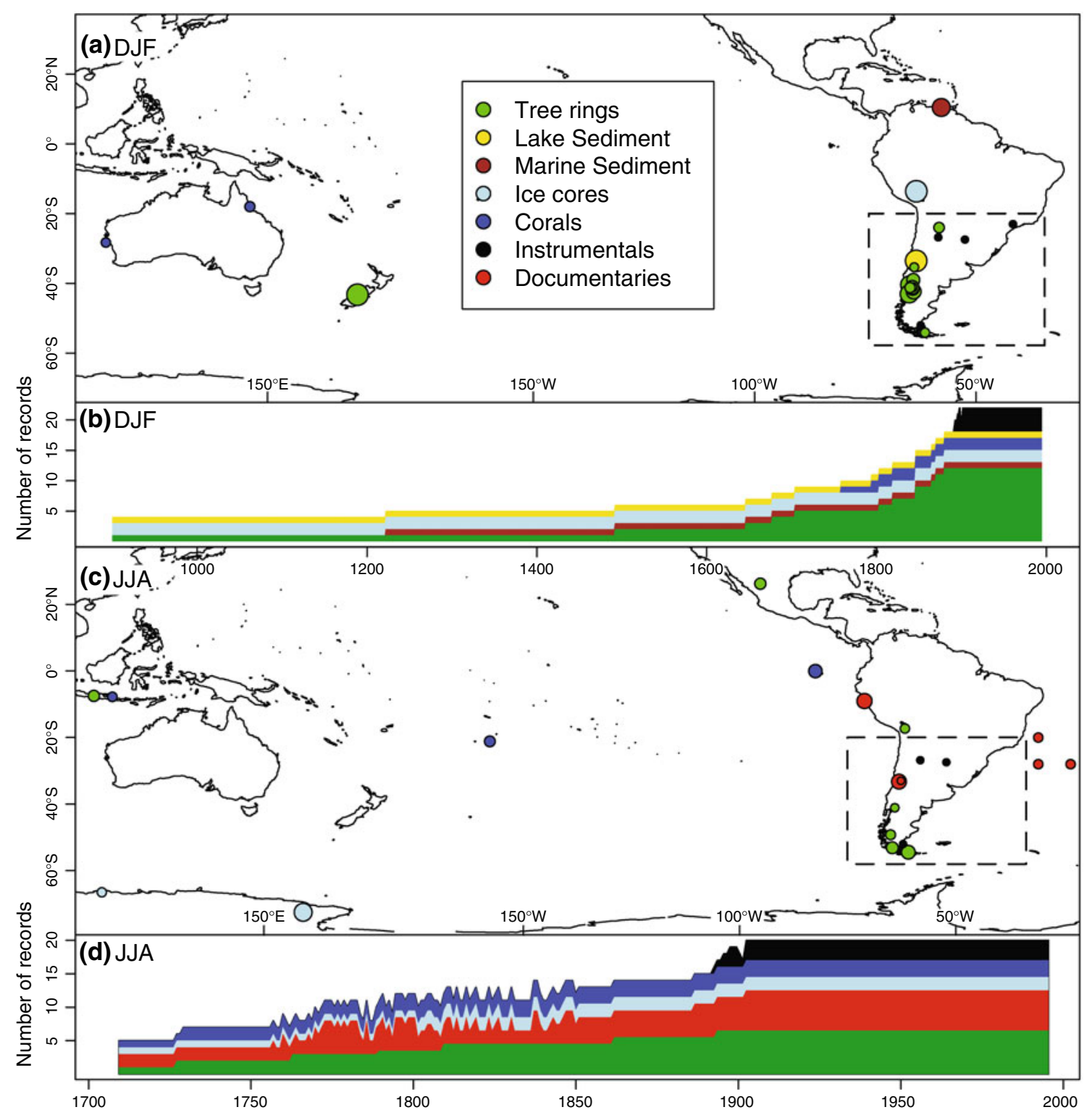

Fig. 1 Locations of the predictors used for the summer (a) and winter (c) reconstructions. The size of the circles represents the lengths of the series (smallest: 109 years, largest: >1,000 years). The colors stand for the proxy type. The reconstruction area is marked by a dashed margin. b, d Show the temporal evolution of the number of records in the final predictor set for summer and winter, respectively well as separately for each grid cell. We used the Reduction of Error (RE, Cook et al. 1994) and $r^{2}$ values as measures of reconstruction skill. These statistics are provided as mean values of three different calibration/verification periods. We retained the first, middle and last thirds of the overlapping period for verification, respectively. Hence, for the SSA mean reconstruction we used 63 years for calibration (1901-1963, 1933-1995 and 1901-1931/ 1964-1995) and 32 years for verification, respectively (1964-1995, 1901-1931 and 1932-1963). Analogous statistics were computed for the spatial reconstructions between 1931 and 1995. As a further test to determine the reliability of the obtained reconstructions, we performed a second, independent reconstruction of SSA mean summer temperatures, using all the 22 summer temperature proxies (see Tables S1-S3) excluded from the optimized predictor set. For winter, the limited number of proxies (seven) that were not included into the optimized predictor matrix did not allow a skillful independent reconstruction.

\section{Results}

The chosen predictor network allows reconstructions of SSA summer and winter temperatures back to 900 and 1706, respectively. We focus on the PCR reconstructions in 
Table 3 Overview of the settings used for the three different techniques we applied for the SSA mean (top) and spatial (bottom) temperature reconstructions

\begin{tabular}{|c|c|c|c|}
\hline & \multicolumn{3}{|l|}{ Reconstruction technique } \\
\hline & PCR & CPS & RegEM \\
\hline \multicolumn{4}{|c|}{ SSA mean reconstructions } \\
\hline Predictors & $\begin{array}{l}\text { First } n \text { PCs explaining } 85 \% \text { of } \\
\text { variance of optimized predictor } \\
\text { set }\end{array}$ & $\begin{array}{l}\text { Proxies of optimized predictor set } \\
\text { with } r \geq 0.1 \text { with the predictand }\end{array}$ & Optimized predictor set \\
\hline Predictand & $\begin{array}{l}\text { First } n \text { PCs explaining } 95 \% \text { of } \\
\text { variance of SSA CRU TS3 grid }\end{array}$ & Spatial average of CRU TS3 grid & $\begin{array}{l}\text { First } n \text { PCs explaining 95\% of } \\
\text { variance of SSA CRU TS3 grid }\end{array}$ \\
\hline Calibration period & $1901-1995$ & $1901-1995$ & $1901-1995$ \\
\hline Settings & OLS regression & $\begin{array}{l}\text { Predictor weighting factor }=r \\
\text { with the predictand }\end{array}$ & $\begin{array}{l}\text { TTLS regularization; Stagn. Tol.: } \\
10^{-4} \text {; Truncation parameter: } 3\end{array}$ \\
\hline \multicolumn{4}{|l|}{ Spatial reconstructions } \\
\hline Predictors & $\begin{array}{l}\text { First } n \text { PCs explaining } 80 \% \text { of } \\
\text { variance of optimized predictor } \\
\text { set }\end{array}$ & $\begin{array}{l}\text { Proxies of optimized predictor set } \\
\text { with } r \geq 0.1 \text { with the predictand }\end{array}$ & Optimized predictor set \\
\hline Predictand & $\begin{array}{l}\text { First } n \text { PCs explaining 95\% of } \\
\text { variance of SSA CRU TS3 grid }\end{array}$ & Each cell of SSA CRU TS3 grid & $\begin{array}{l}\text { First } n \text { PCs explaining 95\% of } \\
\text { variance of SSA CRU TS3 grid }\end{array}$ \\
\hline Calibration period & 1931-1995 & $1931-1995$ & $1931-1995$ \\
\hline Settings & OLS regression & $\begin{array}{l}\text { Predictor weighting factor }=r \\
\text { with the predictand }\end{array}$ & $\begin{array}{l}\text { TTLS regularization; Stagn. Tol.: } \\
10^{-4} \text {; Truncation parameter: } 3\end{array}$ \\
\hline
\end{tabular}

our results and interpretations, because they yielded the highest skill scores (see Sect. 4.3). However, the main conclusions are also valid for CPS and RegEM.

\subsection{SSA mean reconstructions}

The SSA mean PCR summer temperature reconstruction (top) as well as a comparison of the 30-year Gaussian filtered curves of all methods and the associated uncertainties (30-year filtered $2 \mathrm{SE}$; middle) are shown in Fig. 2 (the annual CPS and RegEM reconstructions are shown in Fig. S3). The temperatures are displayed as anomalies with respect to (wrt) the 1901-1995 calibration period. The first 350 years of the reconstruction are relatively warm, interrupted by a colder phase of about 50 years centered around 1140. At the end of the fourteenth century a relatively rapid cooling is found. The anomalously cold conditions last until the beginning of the eighteenth century. The eighteenth century is characterized by relatively warm summer temperatures. Around 1825, there is another rapid temperature decrease with a minimum in the 1850s. SSA summer temperatures thereafter steadily increase until the present. In the period 1901-1995 there is a warming trend of $0.54^{\circ} \mathrm{C} /$ century $\left(0.46^{\circ} \mathrm{C} /\right.$ century in the instrumental data, both with $p<0.0001)$. The reconstructed anomalies of the three likely coldest and warmest summers as well as the corresponding uncertainties are provided in Table 4 (left). The anomalies and uncertainties of the three likely coldest and warmest averages of ten consecutive summers are also shown in Table 4. The 30-year filtered 2 SE uncertainty range (Fig. 2, middle) of the $\mathrm{PCR}$ summer reconstruction is $\pm 0.29^{\circ} \mathrm{C}$ in the year $900, \pm 0.26^{\circ} \mathrm{C}$ in 1750 and $\pm 0.16^{\circ} \mathrm{C}$ in 1900. The corresponding unfiltered interannual uncertainties are $\pm 0.87^{\circ} \mathrm{C}, \pm 0.79^{\circ} \mathrm{C}$ and $\pm 0.53^{\circ} \mathrm{C}$, respectively. In the bottom panel of Fig. 2, the standard deviations of 30year moving windows of the temperatures reconstructed by the three methods are shown.

Figure 3 shows the annually resolved SSA mean PCR winter temperature reconstruction (top) and the comparison of the 30-year filtered reconstruction curves of the three methods (middle; annual CPS and RegEM curves see Fig. S4). Before 1930, the filtered reconstructed winter temperatures mostly remain below the average of the 19011995 calibration period. Short anomalously warm periods of about 10 and 15 years occur around 1815 and 1850 , respectively. Also in winter, there is a warming trend in both the reconstructed $\left(0.46^{\circ} \mathrm{C} /\right.$ century, $\left.p=0.02\right)$ and instrumental $\left(0.51^{\circ} \mathrm{C} /\right.$ century, $\left.p<0.01\right)$ temperatures in the 1901-1995 period. The anomalies and uncertainties of the three likely coldest and warmest reconstructed years and decades are provided in Table 4 (right). The 30-year filtered (interannual) $2 \mathrm{SE}$ uncertainty of the PCR reconstruction is $\pm 0.4^{\circ} \mathrm{C}\left( \pm 1.23^{\circ} \mathrm{C}\right)$ in 1706 and $\pm 0.24^{\circ} \mathrm{C}$ $\left( \pm 0.82^{\circ} \mathrm{C}\right)$ in 1900 . The bottom panel of Fig. 3 displays the 30 -year moving standard deviations of the reconstructions based on the three methods. 


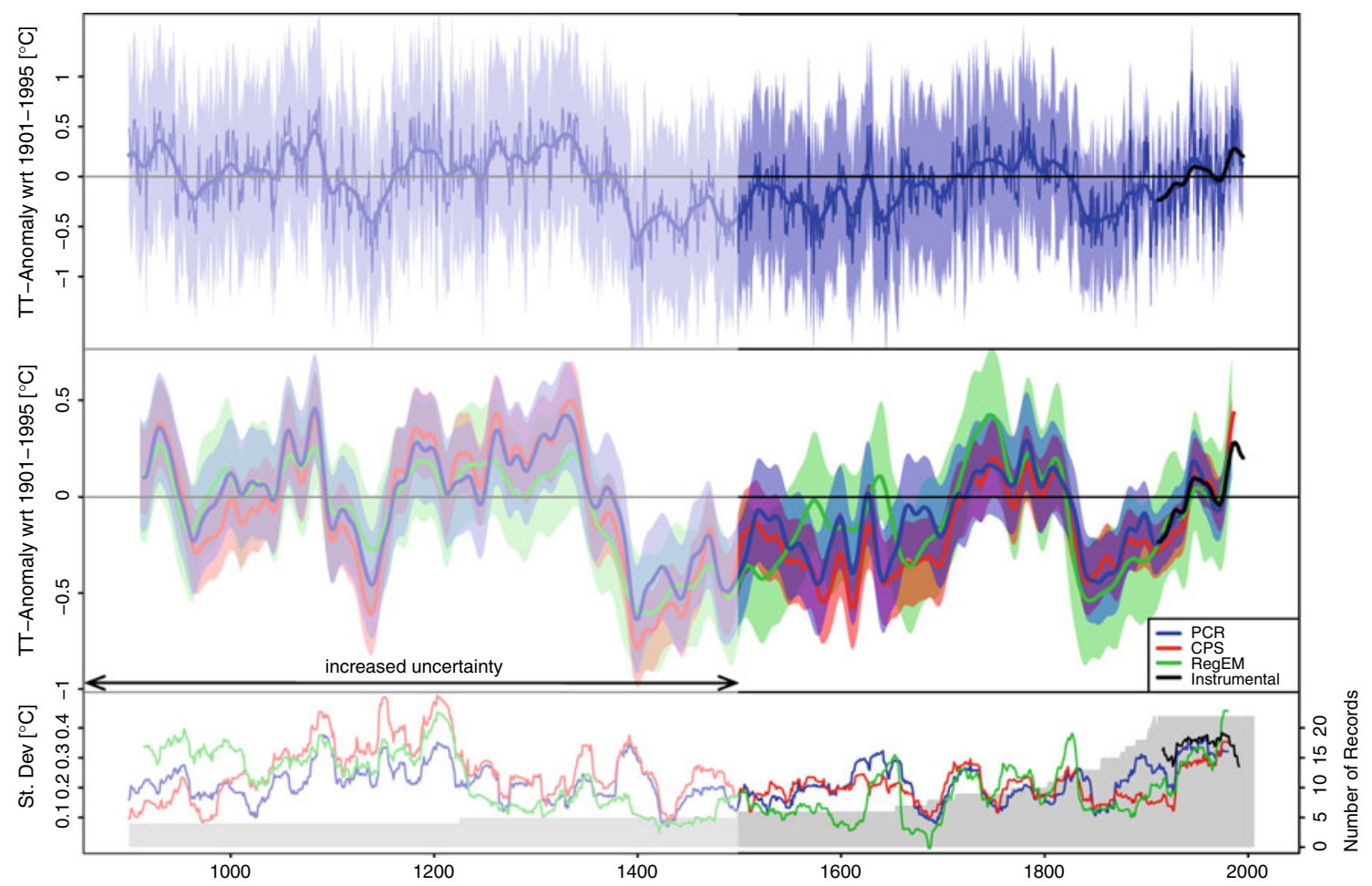

Fig. 2 Top: annual PCR-based reconstructed SSA mean summer (DJF) temperatures 900-1995, anomalous to the calibration period (1901-1995) mean (blue), and associated \pm 2 SE uncertainty bands (shaded). The thick lines are 30-year gaussian filtered reconstructed (blue) and CRU gridded (black) temperatures. Middle 30-year gaussian filtered summer temperatures as in top panel but additionally based on CPS (red) and RegEM (green). The black line is again the instrumental data. The shaded areas represent the filtered $\pm 2 \mathrm{SE}$ uncertainty bands. Bottom 30-year moving standard deviations of the unfiltered reconstructions and CRU gridded data. Shaded is the number of predictors used for the reconstructions at each time step. The period of increased uncertainty due to the reduced predictor set (900-1492; see Sect. 4.3) is indicated by pale colors

Table 4 The three warmest and coldest years and (non-overlapping) decades for summer (DJF) and winter (JJA) reconstructed by PCR

\begin{tabular}{llllll}
\hline & \multicolumn{1}{l}{ DJF } & & JJA & \\
\cline { 2 - 3 } \cline { 5 - 6 } & Years & Decades & & Years & Decades \\
\hline Coldest & $1405\left(-1.05 \pm 0.86^{\circ} \mathrm{C}\right)$ & $1398-1407\left(-0.74 \pm 0.35^{\circ} \mathrm{C}\right)$ & & $1870\left(-1.52 \pm 1.01^{\circ} \mathrm{C}\right)$ & $1861-1870\left(-0.83 \pm 0.41^{\circ} \mathrm{C}\right)$ \\
2nd coldest & $1644\left(-1.03 \pm 0.83^{\circ} \mathrm{C}\right)$ & $1439-1448\left(-0.73 \pm 0.35^{\circ} \mathrm{C}\right)$ & & $1916\left(-1.48 \pm 0.72^{\circ} \mathrm{C}\right)$ & $1823-1832\left(-0.66 \pm 0.45^{\circ} \mathrm{C}\right)$ \\
3rd coldest & $1573\left(-0.97 \pm 0.83^{\circ} \mathrm{C}\right)$ & $1485-1494\left(-0.73 \pm 0.35^{\circ} \mathrm{C}\right)$ & & $1826\left(-1.39 \pm 1.13^{\circ} \mathrm{C}\right)$ & $1915-1924\left(-0.51 \pm 0.29^{\circ} \mathrm{C}\right)$ \\
Warmest & $1945\left(+1.04 \pm 0.49^{\circ} \mathrm{C}\right)$ & $1079-1088\left(+0.57 \pm 0.35^{\circ} \mathrm{C}\right)$ & & $1944\left(+1.47 \pm 0.72^{\circ} \mathrm{C}\right)$ & $1939-1948\left(+0.55 \pm 0.29^{\circ} \mathrm{C}\right)$ \\
2nd warmest & $1205\left(+0.95 \pm 0.87^{\circ} \mathrm{C}\right)$ & $1325-1334\left(+0.49 \pm 0.35^{\circ} \mathrm{C}\right)$ & & $1855\left(+1.32 \pm 1.14^{\circ} \mathrm{C}\right)$ & $1810-1819\left(+0.45 \pm 0.46^{\circ} \mathrm{C}\right)$ \\
3rd warmest & $1218\left(+0.83 \pm 0.87^{\circ} \mathrm{C}\right)$ & $925-934\left(+0.44 \pm 0.35^{\circ} \mathrm{C}\right)$ & & $1761\left(+1.13 \pm 1.2^{\circ} \mathrm{C}\right)$ & $1850-1859\left(+0.34 \pm 0.44^{\circ} \mathrm{C}\right)$ \\
\hline
\end{tabular}

The corresponding anomalies with respect to the period 1901-1995 and uncertainties are indicated in parentheses

\subsection{Spatial SSA reconstructions}

To identify regional differences in the spatial reconstructions, we defined the following four sub-regions (Fig. S5): South Patagonia (SP; all grid cells south of $45^{\circ} \mathrm{S}$ ); North Patagonia (NP, $37^{\circ} \mathrm{S}-45^{\circ} \mathrm{S}$ ), the Central Chile (CC, $27^{\circ} \mathrm{S}-$ $42^{\circ} \mathrm{S}$, along the Pacific coast, average latitudinal extent of four grid boxes) and the remaining areas in subtropical SSA (ST). The 30-year filtered mean summer temperature anomalies of the four regions, reconstructed by PCR (spatial reconstructions), are displayed in Fig. 4. It shows that in summer, the decadal-scale variability is largest in $\mathrm{CC}$, followed by SP and NP. In the ST region, the variability is clearly reduced, as compared to the other regions. These differences in variability between the regions are also visible in the instrumental data, albeit the reduction of variability in ST is smaller (Table S4). Before ca. 1650, the temperatures generally fluctuate synchronously in all 


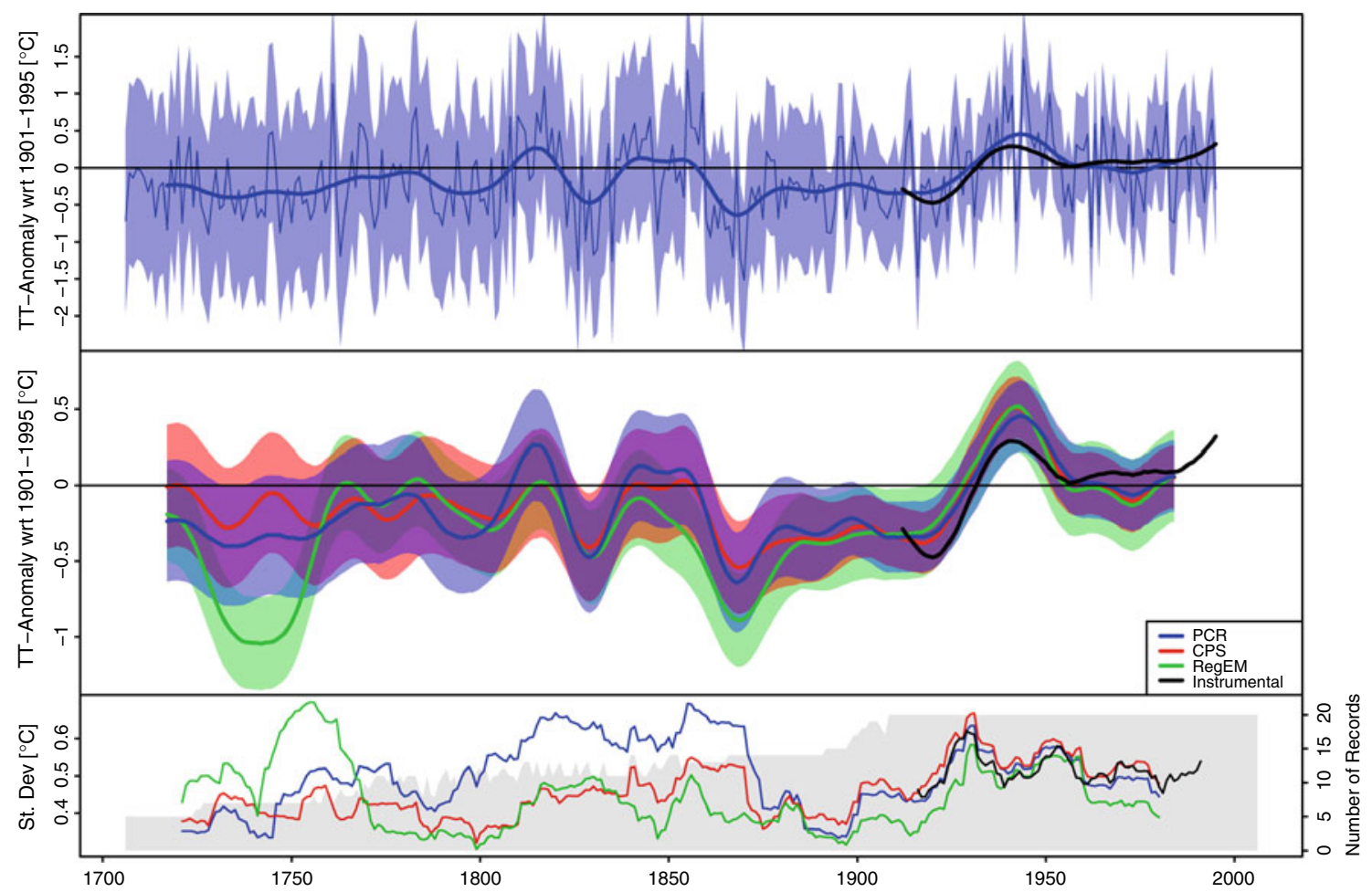

Fig. 3 Same as Fig. 2 but for winter (JJA) and the period 1706-2006. Notice the different scale of the $y$ axes

regions, but with different magnitudes (Fig. 4). Afterwards, the temperature fluctuations of the sub-regions are more variable at the decadal scale, however still synchronous on multi-decadal to centennial scales (e.g. the warm eighteenth and cold nineteenth centuries). The first (second) panel of Fig. 5 displays the mean temperature anomalies of the summers 1846-1875 (1775-1804), being the coldest (warmest) consecutive 30 years of the pre-1901 period $\left(-0.64 \pm 0.34^{\circ} \mathrm{C}\right.$ and $+0.22 \pm 0.39^{\circ} \mathrm{C}$, respectively). In both cases, the temperature pattern is spatially uniform over most of the continent, with some areas in the north showing different sign. The difference between the two periods (warm-cold) is displayed in the third panel of Fig. 5. The largest values correspond to central Patagonia (i.e. the highest amplitude on 30-year timescales in the pre1901 period), while the smallest difference is found in the northernmost areas of SSA. The filtered $2 \mathrm{SE}$ values expressed in ${ }^{\circ} \mathrm{C}$, averaged over the 900-1995 period are shown in the right panel of Fig. 5. The uncertainties are largest in northwestern Argentina and in central Patagonia.

Figure 6 shows the 30-year filtered winter reconstructions of the sub-regions. The differences between the regions are more pronounced than in summer, especially for SP and after 1800. Figure 7 (first two panels) shows average anomalies of the years 1727-1756 (1794-1823), the coldest (warmest) 30 consecutive winters of the 17061900 period $\left(-1.09 \pm 0.75^{\circ} \mathrm{C}\right.$ and $-0.56 \pm 0.65^{\circ} \mathrm{C}$, respectively). The amplitudes (Fig. 7 third panel) are largest in central-northern SSA and smallest in northeastern SSA. The average 30-year filtered SE values 17061995 are displayed in the right panel of Fig. 7. The areas with large uncertainties are more widespread in winter (Fig. 7) than in summer (Fig. 5) and cover large parts of SSA east of the Andes.

\subsection{Quality assessments}

The correlations of the PCR SSA mean reconstructions with the instrumental data in the 1901-1995 period are 0.89 for summer and 0.71 for winter (both $p<0.001$ ). The evolution of the RE and $r^{2}$ values of the SSA mean PCR reconstructions over time as well as the percentage of grid cells with positive REs in the spatial PCR reconstructions are shown in Fig. 8 (corresponding curves for CPS and RegEM, Figs. S6 and S7). The general evolution of the RE and $r^{2}$ values is similar for summer and winter. In the first years of the summer (winter) reconstruction the RE values are very close to zero and remain between 0.2 and 0.4 after 1222 (1787). They reach maximum values of 0.73 (summer) and 0.66 (winter) at the end of the nineteenth century, respectively, where instrumental temperature series become increasingly available (Tables 1,2). The percentage of grid cells with positive REs in the spatial PCR reconstructions (i.e. with higher skill than climatology) is 
Fig. 4 30-year filtered summer temperature anomalies 9001995 (wrt 1901-1995) for different sub-regions of SSA (see Fig. S5) reconstructed by PCR

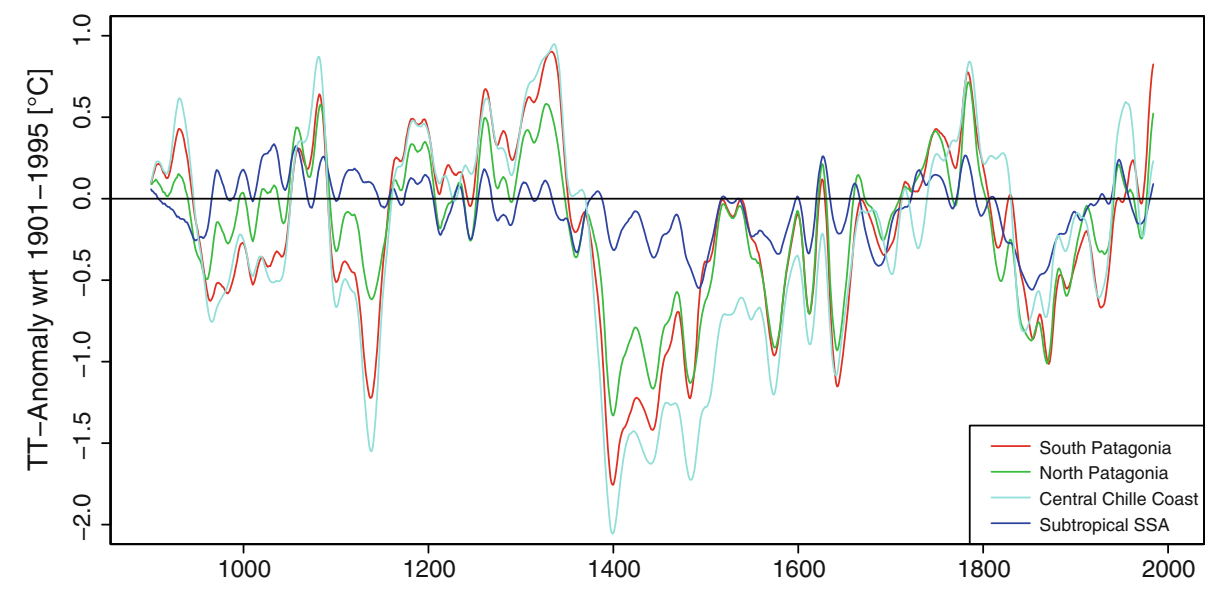

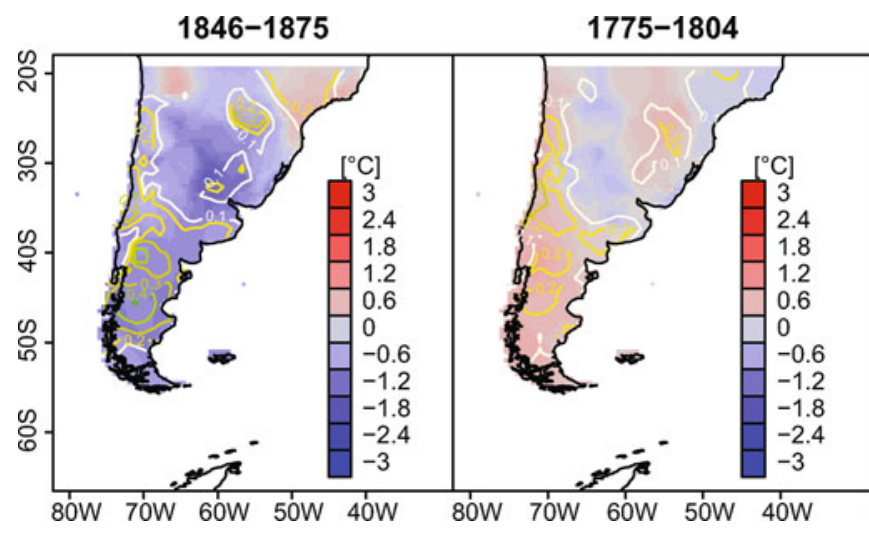

Fig. 5 First (second) panel average temperature anomalies 18461875 (1775-1804), the coldest (warmest) 30 consecutive years of the spatial PCR summer reconstruction. Average REs over the period are indicated by contour lines. Third panel difference between the means of these two periods (warm minus cold). Last panel Mean 30-year filtered uncertainties in the PCR reconstruction (900-1995) relatively stable over time in summer (between 60 and $75 \%$; Fig. 8, red lines). They are clearly lower in winter, starting at $50 \%$ in the early eighteenth century but increasing to $87 \%$ at the end of the reconstruction period. In summer, the lowest RE values are found in the centralnorthern and southernmost parts of SSA; the highest values are located around $45^{\circ} \mathrm{S}$ and in central Chile (contour lines in Fig. 5). In winter, the area with the lowest REs is central SSA east of the Andes; the regions with the highest skill are central and northern Chile (contour lines in Fig. 7). As indicated in Figs. 5 and 7, the spatial distribution of the REs remains rather stable over time.

Figure 9a shows the 30-year Gaussian filtered SSA mean summer PCR reconstruction (blue) along with the independent PCR reconstruction based on the 22 withheld summer predictors (green). Due to the limited number of available predictors, the reconstruction based on the withheld predictors yielded skillful results $(\mathrm{RE}>0)$ only back to 1232. Although the amplitudes of the two curves differ, the temporal evolutions of the two reconstructions are similar on centennial timescales. The red curve in Fig. 9a shows the reconstruction obtained when only using those proxies of the optimal set which are from within SSA. It covers the period 1677 (four SSA predictors available) to 1995. The decadal scale variations are very similar to the original reconstruction and the correlations between the two reconstructions are 0.82 on interannual and 0.95 on 30 year timescales (both $p<0.001$ ). Also in winter, the reconstruction based only on proxies from within SSA (covering 1807, where four proxies are available, to 1995) is very similar to that based on the optimized predictor set (Fig. 9b). Here, the correlations are 0.81 (interannual) and 0.92 (30 year-filtered; both $p<0.001$ ).

As a further validation, we compared our results with the annual temperature reconstructions of the NP and SP Andes (Villalba et al. 2003) based on tree ring records independent from our reconstructions. For comparison, we constructed annual mean values of our results by averaging the reconstructed summer and winter anomalies. The 30year filtered anomalies of both reconstructions are shown in Figs. 9c (NP) and d (SP). The correlations between our SP (NP) annual reconstructions and the results of Villalba 
Fig. 6 Same as Fig. 4 but for winter and the period 1706 1995. Notice the different scale of the $y$-axis

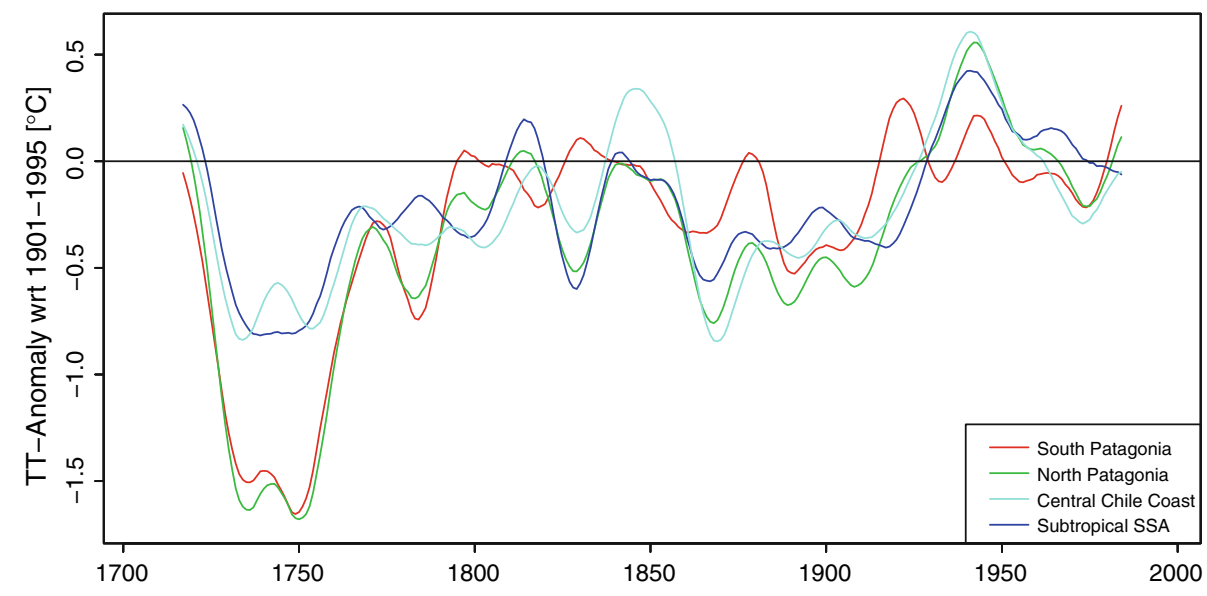

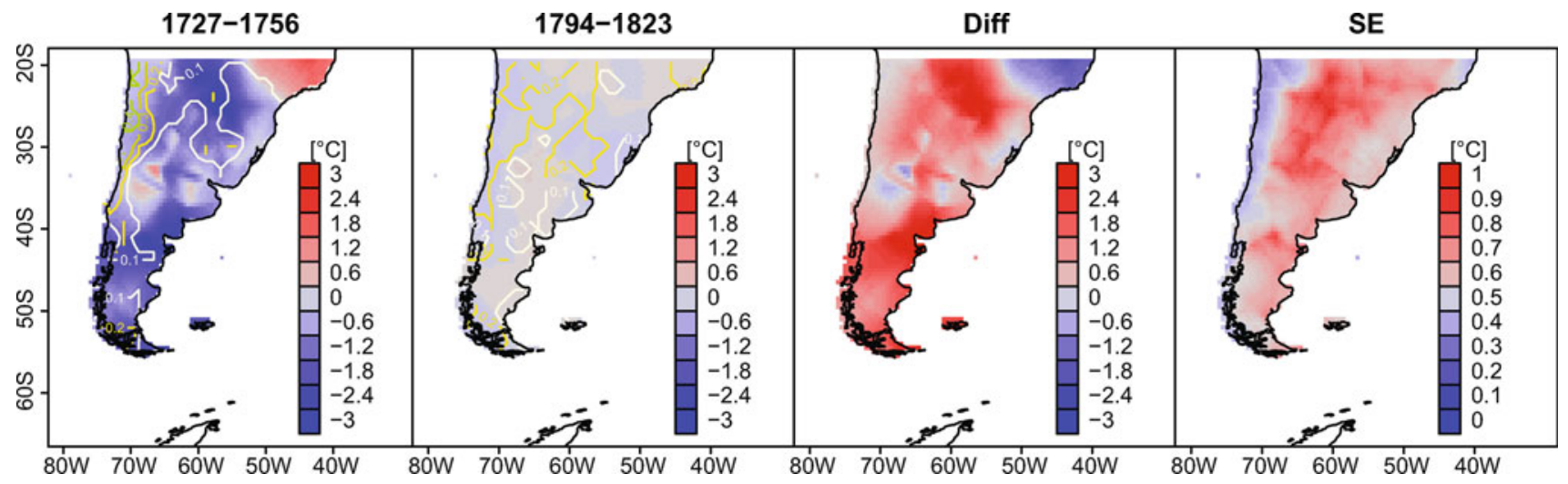

Fig. 7 Same as Fig. 5 but for winter and the coldest (warmest) period 1727-1756 (1794-1823)

et al. (2003) are $0.28(0.31)$ for the unfiltered and 0.37 (0.71) for the 30 -year filtered data and are significant $(p<0.001)$. However, our results do not depict the strong negative anomalies in the seventeenth and eighteenth centuries found in SP by Villalba et al. (2003; Fig. 9d).

Finally, we calculated the correlations of long (nonhomogenized) instrumental temperature records with the spatial reconstructions at the corresponding grid cells (Table 5). As long records, we defined stations with available data for at least 30 years in both the calibration (19311995) and reconstruction (pre-1931) periods (sources: GHCN; Peterson and Vose 1997 and Servicio Meteorologico Nacional de Argentina, personnal communication 2008). Significant correlations $(p<0.01)$ are marked with an asterisk (Table 5). Most stations have significant but not very high correlations ( $r=0.55$ on average). Most of the station data with non-significant correlations have either non-significant correlations also in the calibration period (1931-1995) or do not correlate significantly with the corresponding predictand grid cell in the verification period. Non-significant correlations mainly occur at stations in southern Patagonia or in the northeastern part of SSA.

\section{Discussion}

\subsection{SSA mean reconstructions}

Our summer temperature reconstructions (Fig. 2) suggest that a warm period extended in SSA from 900 (or even earlier) to the mid-fourteenth century. This is towards the end of the Medieval Climate Anomaly (MCA; Bradley et al. 2003; Stine 1994) as concluded from NH temperature reconstructions, where most studies find a termination between ca. 1200-1350 (Jansen et al. 2007; Wanner et al. 2008). Major advances of several summer temperature sensitive glaciers from the eastern slopes of the Patagonian Andes occurred in the seventeenth century and between 1850 and 1950 (Koch and Kilian 2005; Luckman and Villalba 2001), coinciding with periods of low temperatures in our reconstruction (Fig. 2). However, the reconstructed cold period in the early fifteenth century corresponds only for a few SSA glaciers with a period of advance (e.g. Glaciar Huemul, Masiokas et al. 2009; Röthlisberger 1986). This may be due to the still limited knowledge about glacial fluctuations in the area and their 
Fig. 8 Skill measures of the PCR reconstructions. RE (black) and $r^{2}$ (green) of the SSA mean reconstructions as well as the fraction of grid cells with positive RE values of the spatial reconstructions (red). Top summer 900-1995. Bottom winter 1706-1995. The values represent averages of three calibration/verification intervals (see text for details)
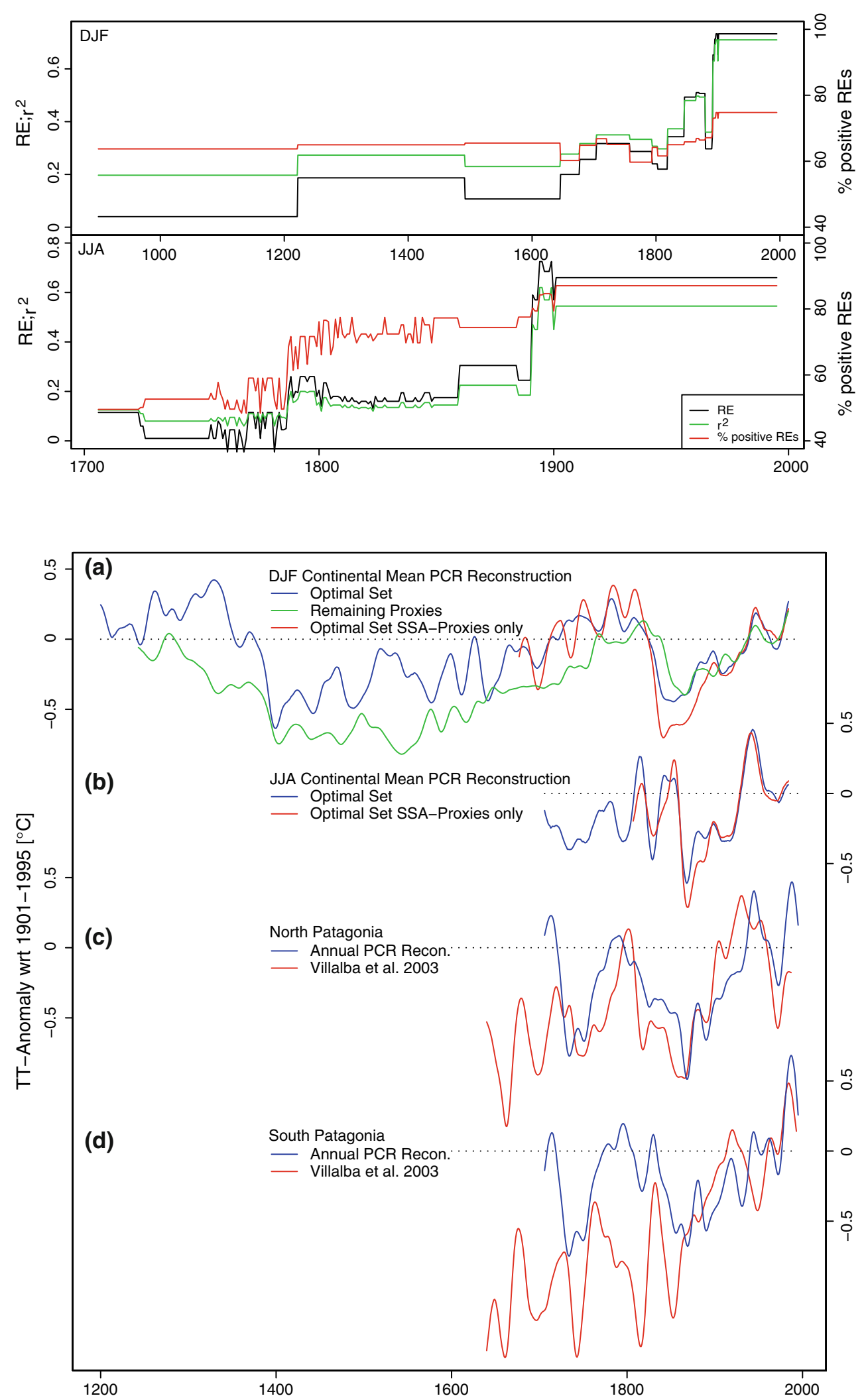

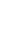

Fig. 9 a 30-year filtered SSA mean summer temperatures reconstructed by PCR using all proxies of the optimized predictor set (blue; 1200-1995), the withheld summer temperature predictors (green; 1232-1995) and only the proxies of the optimized set that are situated within SSA (red; 1677-1995). b 30-year filtered SSA mean winter temperatures reconstructed by PCR using all proxies of the optimized predictor set (blue; 1706-1995) and only the proxies of the optimized set that are situated within SSA (red; 1807-1995). 30-year filtered reconstructed annual (average of DJF and JJA) anomalies (blue; 17061995) for North Patagonia (c) and South Patagonia (d) compared to the independent reconstructions of Villalba et al. (2003; red; 1640-1995)

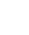

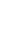


Table 5 Long instrumental temperature stations used for verification

\begin{tabular}{lllllll}
\hline Station name & Start & End & Lat S & Lon W & cor DJF & cor JJA \\
\hline Ushuaia & 1901 & 1986 & 54.8 & 68.32 & $0.38^{\mathrm{a}}$ & $0.63^{*}$ \\
Punta Arenas & 1888 & 1991 & 53 & 70.85 & $0.08^{\mathrm{b}}$ & 0.34 \\
Santa Cruz Aero & 1901 & 1989 & 50.02 & 68.57 & $0.28^{\mathrm{a}}$ & $0.71^{*}$ \\
Trelew Aero & 1901 & 1989 & 43.2 & 65.27 & $0.51^{*}$ & $0.3^{\mathrm{a}}$ \\
Esquel & 1901 & 1983 & 42.97 & 71.15 & $0.49^{*}$ & $0.07^{\mathrm{b}}$ \\
Bahia Blanca Aero & 1860 & 1989 & 38.7 & 62.2 & $0.41^{*}$ & 0.32 \\
Prado & 1883 & 1988 & 34.85 & 56.2 & $0.67^{*}$ & $0.69^{*}$ \\
Buenos Aires & 1856 & 1989 & 34.58 & 58.48 & $0.57^{*}$ & $0.43^{*}$ \\
Pudahuel & 1861 & 2008 & 33.38 & 70.78 & $0.35^{*}$ & $0.65^{*}$ \\
San Juan & 1901 & 1985 & 31.57 & 68.87 & $0.77^{*}$ & $0.52^{*}$ \\
Cordoba & 1873 & 1986 & 31.4 & 64.2 & $0.69^{*}$ & $0.4^{*}$ \\
Punta Tortuga & 1901 & 1980 & 29.9 & 71.4 & $0.51^{*}$ & $0.66^{*}$ \\
Goya & 1877 & 1960 & 29.1 & 59.3 & $0.59^{*}$ & $0.73^{*}$ \\
Curitiba & 1885 & 1991 & 25.43 & 49.27 & $0.5^{*}$ & $0.53^{*}$ \\
Asuncion Aero & 1893 & 1990 & 25.27 & 57.63 & 0.39 & $0.71^{*}$ \\
Salta Aero & 1901 & 1989 & 24.85 & 65.48 & $0.81^{*}$ & $0.65^{*}$ \\
Iguape & 1895 & 1987 & 24.72 & 47.55 & $0.2^{\mathrm{a}}$ & 0.19 \\
Sao Paolo & 1887 & 1991 & 23.5 & 46.62 & $0.4^{*}$ & $0.33^{\mathrm{a}}$ \\
Rio de Janeiro & 1871 & 1990 & 22.92 & 43.17 & $0.38^{*}$ & $0.38^{*}$ \\
\hline Stion & 1950 & & & & &
\end{tabular}

Station names, beginning and end years of the measurements and coordinates. Correlations with the spatial summer and winter PCR reconstructions at the corresponding grid cells in the pre-1931 overlap periods

${ }^{\text {a }}$ Correlation of station data with the predictand is not significant in the verification period

${ }^{\mathrm{b}}$ Correlation is not significant also in the calibration period

* Significant correlations $(p<0.01)$

2009) mostly coincide with cold periods in our SSA summer temperature reconstructions. This is also confirmed if the proxy record from New Zealand is removed from the predictor set (Fig. S8). This suggests that the teleconnections between the SSA and New Zealand areas as found in the instrumental record (e.g. Villalba et al. 1997b) were persistent over the last millennium. The warm temperatures reconstructed in the twentieth century are of similar amplitude as in preceding warm periods within the last millennium (Fig. 2).

\subsection{Spatial reconstructions}

The temperature variations of the different sub-regions of SSA are broadly synchronous at multi-decadal to centennial scales, albeit with different amplitudes (Figs. 4, 6). At annual to decadal timescales (except for the pre-1650 period in summer), the temperatures of the sub-regions exhibit more individual fluctuations (Figs. 4, 5, 6, 7 and S9, S10), but remain mostly within the 2 SE uncertainty bands of each individual region (not shown). The strong synchronicity in summer temperatures before $1650 \mathrm{might}$ be an artifact caused by the decreasing number of available predictors back in time leading to reduced spatial variability and more fitting towards mean conditions. As also found in regional reconstructions from the $\mathrm{NH}$ and the tropics (Jansen et al. 2007; Rabatel et al. 2008; Wanner et al. 2008), the timing and extent of the warmest and coolest periods in our reconstructions vary in different parts of SSA (Fig. 4): The warm peaks between 900 and 1350 are distinct in SP, NP and CC with 30-year filtered anomalies of up to $+0.9^{\circ} \mathrm{C}$ (wrt 1901-1995, Fig. 4) in the late thirteenth and early fourteenth centuries. In these regions, the transition to colder conditions is characterized by two rapid temperature decreases between 1335 and 1355 as well as between 1370 and 1400 . The reconstructions of the ST region can be clearly distinguished from the other regions due to the weak warm anomalies before 1350, the absence of the distinct cool period at the beginning of the fifteenth century and the pronounced minimum around 1850 in summer (Fig. 4). The distinct differences in variability between the sub-regions may also be an artifact of the strong limitations of the instrumental target in broad regions of SSA due to the sparse coverage with station data (Garreaud et al. 2009; see also Fig. S2).

\subsection{Quality considerations}

The three methodologies used herein (PCR, CPS and RegEM) lead to comparable reconstructions at decadal to centennial timescales (Figs. 2, 3, middle panels and Figs. S3, S4, S6, S7, S11, S12). Particularly the results of PCR and CPS are remarkably similar, with a slightly different temperature history estimated by RegEM (Figs. 2, 3). The bottom panels of Figs. 2 and 3 suggest that none of the applied methods systematically over- or under-estimates the interannual variance back in time. We mainly base our discussions on the results of PCR, because this method yielded the highest skill scores (Figs. S6, S7). The PCR and CPS reconstructions are relatively robust to changes in reconstruction parameters, calibration period (see Figs. S13, S14) or predictor subset (see Figs. 9, S11). In contrast, the results of the RegEM reconstructions are sensitive to changes in the truncation parameter, predictor set and calibration period chosen; particularly in the spatial reconstructions with short calibration periods (see e.g., Fig. S11). The summer temperature reconstruction, which we performed based on a completely independent predictor set (see Sect. 3.3), has a qualitatively similar pattern at centennial timescales (Fig. 9). Also, the reconstructions based only on predictors from within SSA are very similar to the results of our optimized sets in both seasons (Fig. 9), indicating that including proxies from areas outside SSA does not lead to biases in our reconstructions, at least as 
regards the SSA mean. Moreover, our reconstructions are not dominated by single proxies, as shown by the individual regression weights of each proxy in PCR (Figs. S15-S18). We therefore argue that the reconstructed low frequency patterns are relatively robust with respect to the reconstruction methodology and predictor set used.

Our results suggest that the selected predictors are able to capture regional differences in past SSA temperatures at interannual (illustrated by Figs. S9, S10) and decadal timescales (Figs. 4, 5, 6, 7, 9). This finding is corroborated by the significant correlations with the independent regional reconstructions of the southern Andes (Villalba et al. 2003) and the long temperature measurements from SSA (Table 5). However, most of these correlations are significant though rather low, indicating that our reconstructions have limited potential for local to regional analyses in the complex mountain areas of the Andes and in the peripheral regions of SSA.

The reconstruction uncertainties are smaller in summer than in winter (Figs. 2, 3, 5, 7, S9 and S10), indicating that the quality of the predictor network is higher in summer. Generally, our reconstructions and verification exercises yielded mostly positive but relatively low skill scores for both seasons (Figs. 5, 7, 8). It must be noted that we optimized our predictor set based on these skill scores which are, therefore, very probably overestimated to a certain extent. The lowest skill and the largest uncertainties (Figs. 5, 7) correspond mostly to the lowlands east of the Andes, from where no annually resolved temperature proxies are available (Fig. 1). We emphasize that in the period before 1493, the summer temperature reconstructions exhibit larger uncertainties (as illustrated in Fig. 2), because all but one predictor used in this timeframe stem from outside SSA and are only connected to its climate through teleconnections which are assumed to remain stable over time. However, Fig. S8 shows that the record from within SSA has the largest influence on the reconstruction in this period (900-1492). Furthermore, a reconstruction based only on SSA proxies (some of them not included in the optimal set) reveals similar results. This indicates that the reconstructions reflect realistic fluctuations of SSA temperatures, also in this early period (details see supplementary material). The results are generally more uncertain in winter than in summer, because in winter, the relation to SSA winter temperature is found by correlation analysis only and has not been explicitly stated in literature for most of the non-instrumental proxies used. The only exception are the tree ring records from South Patagonia and Tierra del Fuego, which Aravena et al. (2002) found to be related to annual minimum temperatures. These findings underline the need for more highly resolved temperature proxies from within SSA, particularly in other seasons than summer and in the eastern part of the continent.

\section{Conclusions and outlook}

Twenty two (20) carefully selected proxies were used to statistically reconstruct austral summer (winter) temperatures of SSA back to 900 (1706) using PCR, CPS and RegEM. The results represent the first seasonal sub-continental-scale climate field reconstructions of the SH going so far back in time. The reconstructed SSA mean summer temperatures are characterized by warm episodes before 1350, between 1710 and 1820 and after 1940. Cold conditions prevailed between 1400 and 1650 as well as between 1820 and 1940. This mostly agrees with reconstructions of fluctuations of temperature sensitive glaciers in SSA and New Zealand. In winter, the decadal-scale pre1901 temperature anomalies mostly remain below the twentieth century average. Within the twentieth century, the 30-year filtered anomalies of both seasons do not exceed the uncertainty range of warm periods in previous centuries. Our spatial reconstructions indicate differences in the low and high frequency variability between the subregions of SSA. This study clearly revealed that temporally and spatially highly resolved multi-centennial climate field reconstructions are also possible in the SH. Nevertheless, skill values are still rather low and there is a striking lack of annually resolved proxy data, especially from tropical and subtropical regions (see Boninsegna et al. 2009) and from the eastern lowlands of SSA.

Together with reconstructions from other regions, our reconstructions allow quantification of differences and similarities of past temperature variations of different continents and hemispheres and to put the recent warming into a larger temporal and spatial context (as intended by the PAGES 2k initiative; Newman et al. 2009). Besides, they can serve as a basis for the analysis of environmental and societal changes of the last millennium in SSA as well as for comparison and calibration issues of proxies with lower resolution. Along with forthcoming reconstructions of precipitation (Neukom et al. 2010) and sea level pressure, our results will help to understand the influence of globally relevant large scale patterns, such as ENSO, SAM and PDO on the climate of SSA as well as regional expressions of solar and volcanic forcings. Finally, the reconstructions can be used for comparison with the outputs of global climate model (GCM) simulations (Meyer and Wagner 2008a, b. Such comparisons can help to improve the understanding of the processes driving past climate variability in SSA and also to assess and ultimately improve the ability of GCMs to simulate past and future climate variability.

Acknowledgments $\mathrm{RN}$ is supported by the by the Swiss NSF through the NCCR Climate. JL acknowledges support from the EU/ FP7 project ACQWA (grant 212250). We thank the Servicio 
Meteorologico Nacional de Argentina and Gustavo Naumann for kindly providing the station data. We also thank Jan Esper and Ulf Büntgen for support in the development of the tree ring chronologies. Many thanks go to all contributors of proxy data and to PAGES for supporting the initiative LOTRED South America. The reviewers made useful comments and suggestions and helped to improve the quality of this study.

\section{References}

Aravena JC, Lara A, Wolodarsky-Franke A, Villalba R, Cuq E (2002) Tree-ring growth patterns and temperature reconstruction from Nothofagus pumilio (Fagaceae) forests at the upper tree line of southern Chilean Patagonia. Revista Chilena De Historia Natural 75:361-376

Black DE, Abahazi MA, Thunell RC, Kaplan A, Tappa EJ, Peterson LC (2007) An 8-century tropical Atlantic SST record from the Cariaco Basin: Baseline variability, twentieth-century warming, and Atlantic hurricane frequency. Paleoceanography 22: PA4204

Boninsegna JA, Keegan J, Jacoby GC, D'Arrigo R, Holmes RL (1989) Dendrochronological studies in Tierra del Fuego, Argentina. Quat South Am 7:315-326

Boninsegna JA et al (2009) Dendroclimatological reconstructions in South America: a review. Palaeogeogr Palaeoclimatol Palaeoecol 281:210-228

Bradley RS, Hughes MK, Diaz HF (2003) Climate in Medieval time. Science 302:404-405

Briffa KR, Osborn TJ, Schweingruber FH, Jones PD, Shiyatov SG, Vaganov EA (2002) Tree-ring width and density data around the Northern Hemisphere: Part 1, local and regional climate signals. Holocene 12:737-757

Brohan P, Kennedy JJ, Harris I, Tett SFB, Jones PD (2006) Uncertainty estimates in regional and global observed temperature changes: a new data set from 1850. J Geophys Res Atmos. 111: $21 \mathrm{p}$

Busalacchi AJ (2004) The role of the Southern Ocean in global processes: an earth system science approach. Antarct Sci $16: 363-368$

Cook ER, Briffa KR, Jones PD (1994) Spatial regression methods in dendroclimatology - a review and comparison of 2 techniques. Int J Climatol 14:379-402

Cook ER, Palmer JG, D'Arrigo RD (2002) Evidence for a 'Medieval Warm Period' in a 1, 100 year tree-ring reconstruction of past austral summer temperatures in New Zealand. Geophys Res Lett 29:1667

Cook ER, Woodhouse CA, Eakin CM, Meko DM, Stahle DW (2004) Long-term aridity changes in the western United States. Science 306:1015-1018

D'Arrigo R et al (2006) Monsoon drought over Java, Indonesia, during the past two centuries. Geophys Res Lett 33:L04709

Dettinger MD, Battisti DS, Garreaud RD, McCabe GJ, Bitz CM (2001) Interhemispheric effects of interannual and decadal ENSO-like climate variations on the Americas. In: Markgraf V (ed) Interhemispheric climate linkages. Cambridge University Press, Cambridge, pp 1-16

Dunbar RB, Wellington GM, Colgan MW, Glynn PW (1994) Eastern Pacific sea-surface temperature since 1600-AD—the delta-O-18 record of climate variability in Galapagos corals. Paleoceanography 9:291-315

Esper J, Frank DC, Wilson RJS, Briffa KR (2005) Effect of scaling and regression on reconstructed temperature amplitude for the past millennium. Geophys Res Lett 32:L07711
Frank D, Esper J, Cook ER (2007) Adjustment for proxy number and coherence in a large-scale temperature reconstruction. Geophys Res Lett 34:L16709

García-Herrera R, Konnen GP, Wheeler DA, Prieto MR, Jones PD, Koek FB (2005) CLIWOC: A climatological database for the world's oceans 1750-1854. Clim Change 73:1-12

García-Herrera R et al (2008) A chronology of El Niño events from primary documentary sources in northern Peru. J Clim 21:19481962

Garreaud RD, Battisti DS (1999) Interannual (ENSO) and interdecadal (ENSO-like) variability in the Southern Hemisphere tropospheric circulation. J Clim 12:2113-2123

Garreaud RD, Vuille M, Compagnucci R, Marengo J (2009) Presentday South American climate. Palaeogeogr Palaeoclimatol Palaeoecol 281:180-195

Jansen E et al (2007) Palaeoclimate, in Climate Change 2007: the physical science basis. In: Solomon $\mathrm{S}$ et al (ed) Contribution of working group I to the fourth assessment report of the intergovernmental panel on climate change. Cambridge, United Kingdom and New York, NY, USA

Jones PD, Briffa KR, Barnett TP, Tett SFB (1998) High-resolution palaeoclimatic records for the last millennium: interpretation, integration and comparison with General Circulation Model control-run temperatures. Holocene 8:455-471

Jones PD et al (2009) High-resolution palaeoclimatology of the last millennium: a review of current status and future prospects. Holocene 19:3-49

Koch J, Kilian R (2005) 'Little Ice Age' glacier fluctuations, Gran Campo Nevado, southernmost Chile. Holocene 15:20-28

Kuhnert H et al (1999) A 200-year coral stable oxygen isotope record from a high-latitude reef off western Australia. Coral Reefs 18:1-12

Küttel M, Luterbacher J, Zorita E, Xoplaki E, Riedwyl N, Wanner H (2007) Testing a European winter surface temperature reconstruction in a surrogate climate. Geophys Res Lett 34:L07710

Küttel M et al (2009) The importance of ship log data: reconstructing North Atlantic, European and Mediterranean sea level pressure fields back to 1750. Clim Dyn. doi:10.1007/s00382-0000900577-00389

Lamarche VC, Holmes RL, Dunwiddie PW, Drew LG (1979) Treering chronologies of the southern hemisphere: vol 1: Argentina. Chronology Series V, Laboratory of Tree-Ring Research. University of Arizona, Tucson

Lara A, Villalba R (1993) A 3620-year temperature record from Fitzroya-Cupressoides tree rings in Southern South-America. Science 260:1104-1106

Lara A, Aravena JC, Villalba R, Wolodarsky-Franke A, Luckman B, Wilson R (2001) Dendroclimatology of high-elevation Nothofagus pumilio forests at their northern distribution limit in the central Andes of Chile. Can J Forest Res 31:925-936

Lara A, Villalba R, Wolodarsky-Franke A, Aravena JC, Luckman $\mathrm{BH}$, Cuq E (2005) Spatial and temporal variation in Nothofagus pumilio growth at tree line along its latitudinal range (35 degrees 40 ' -55 degrees S) in the Chilean Andes. J Biogeogr $32: 879-893$

Lara A, Villalba R, Urrutia R (2008) A 400-year tree-ring record of the Puelo River summer-fall streamflow in the Valdivian Rainforest eco-region, Chile. Clim Change 86:331-356

Linsley BK, Wellington GM, Schrag DP (2000) Decadal sea surface temperature variability in the subtropical South Pacific from 1726 to 1997 AD. Science 290:1145-1148

Ljungqvist FC (2009) Temperature Proxy Records covering the last two Millennia: a tabular and visual Overview. Geografiska Annaler: Ser A, Phys Geogr 91:11-29

Luckman B, Villalba R (2001) Assessing the synchronicity of glacier fluctuations in the western Cordillera of the Americas during the 
last millennium. In: Markgraf V (ed) Inter-hemispheric climate linkages. Academic Press, San Diego, pp 119-140

Luterbacher J et al (2002) Reconstruction of sea level pressure fields over the Eastern North Atlantic and Europe back to 1500. Clim Dyn 18:545-561

Luterbacher J, Dietrich D, Xoplaki E, Grosjean M, Wanner H (2004) European seasonal and annual temperature variability, trends, and extremes since 1500. Science 303:1499-1503

Luterbacher J, Liniger MA, Menzel A, Estrella N, Della-Marta PM, Pfister C, Rutishauser T, Xoplaki E (2007) The exceptional European warmth of autumn 2006 and winter 2007: historical context, the underlying dynamics and its phenological impacts. Geophys Res Lett 34:L12704

Mann ME, Jones PD (2003) Global surface temperatures over the past two millennia. Geophys Res Lett 30:1820

Mann ME, Bradley RS, Hughes MK (1998) Global-scale temperature patterns and climate forcing over the past six centuries. Nature 392:779-787

Mann ME, Rutherford S, Wahl E, Ammann C (2007) Robustness of proxy-based climate field reconstruction methods. J Geophys Res 112:D12109

Mann ME, Zhang ZH, Hughes MK, Bradley RS, Miller SK, Rutherford S, Ni FB (2008) Proxy-based reconstructions of hemispheric and global surface temperature variations over the past two millennia. Proc Natl Acad Sci USA 105:13252-13257

Mann ME et al (2009) Global signatures and dynamical origins of the little ice age and medieval climate anomaly. Science 326:12561260

Masiokas MH, Luckman BH, Villalba R, Delgado S, Skvarca P, Ripalta A (2009) Little Ice Age fluctuations of small glaciers in the Monte Fitz Roy and Lago del Desierto areas, south Patagonian Andes, Argentina. Palaeogeogr Palaeoclimatol Palaeoecol 281:351-362

McCulloch M, Fallon S, Wyndham T, Hendy E, Lough J, Barnes D (2003) Coral record of increased sediment flux to the inner Great Barrier Reef since European settlement. Nature 421:727-730

Meyer I, Wagner S (2008a) The Little Ice Age in southern South America: proxy and model based evidence. In: Vimeux $\mathrm{F}$ et al (eds) Past climate variability in South America and surrounding regions from the last glacial maximum to the Holocene, pp 395-412. doi:10.1007/978-90-481-2672-9

Meyer I, Wagner S (2008b) The Little Ice Age in southern Patagoniacomparison between paleo-ecological reconstructions and downscaled model output of a GCM simulation. PAGES News 16(2):12-13

Mitchell TD, Jones PD (2005) An improved method of constructing a database of monthly climate observations and associated highresolution grids. Int J Climatol 25:693-712

Morales MS, Villalba R, Grau HR, Paolini L (2004) Rainfallcontrolled tree growth in high-elevation subtropical treelines. Ecology 85:3080-3089

Neukom R et al (2009) An extended network of documentary data from South America and its potential for quantitative precipitation reconstructions back to the 16th century. Geophys Res Lett 36:L12703

Neukom $R$ et al (2010) Multi-centennial summer and winter precipitation variability in southern South America. Geophys Res Lett (revised)

Newman L, Wanner H, Kiefer T (2009) Towards a global synthesis of the climate of the last two millennia. PAGES news 17:130-131

Peterson TC, Vose RS (1997) An overview of the global historical climatology network temperature database. Bull Am Meteorol Soc 78:2837-2849

Prieto MDR, García Herrera R (2009) Documentary sources from South America: Potential for climate reconstruction. Palaeogeogr Palaeoclimatol Palaeoecol 281:196-209
Prieto MR, Herrera R, Castrillejo T, Dussel P (2001a) Variaciones climáticas recientes y disponibilidad hídrica en los Andes Centrales Argentino-Chilenos (1885-1996). El uso de datos periodísticos para la reconstitución del clima. Meteorológica 25:27-43

Prieto MR, Herrera R, Dussel P, Gimeno L, Ribera P, Garcia R, Hernandez E (2001b) Interannual oscillations and trend of snow occurrence in the Andes region since 1885. Aust Meteorol Mag 50:164-168

Quinn WH, Neal VT (1992) The historical record of El Niño events. In: Bradley R, Jones PD (eds) Climate since A.D. 1500. Routledge, London, pp 623-648

Rabatel A, Francou B, Jomelli V, Naveau P, Grancher D (2008) A chronology of the Little Ice Age in the tropical Andes of Bolivia (16 degrees $\mathrm{S}$ ) and its implications for climate reconstruction. Quat Res 70:198-212

Riedwyl N, Luterbacher J, Wanner H (2008) An ensemble of European summer, winter temperature reconstructions back to 1500. Geophys Res Lett 35:L20707

Riedwyl N, Küttel M, Luterbacher J, Wanner H (2009) Comparison of climate field reconstruction techniques: application to Europe. Clim Dyn 32:381-395

Röthlisberger F (1986) 10000 Jahre Gletschergeschichte der Erde, Verlag Sauerländer, Aarau

Rutherford S, Mann ME, Osborn TJ, Bradley RS, Briffa KR, Hughes MK, Jones PD (2005) Proxy-based Northern Hemisphere surface temperature reconstructions: sensitivity to method, predictor network, target season, and target domain. J Clim 18:2308-2329

Schaefer JM et al (2009) High-frequency holocene glacier fluctuations in New Zealand differ from the northern signature. Science 324:622-625

Scherrer SC, Appenzeller C (2006) Swiss Alpine snow pack variability: major patterns and links to local climate and largescale flow. Clim Res 32:187-199

Schmelter A (2000) Climatic response and growth-trends of Nothofagus pumilio along altitudinal gradients from arid to humid sites in northern Patagonia - a progress report. In: Roig F (ed) Dendrochronología en América Latina. Editorial Nacional de Cuyo, Mendoza, pp 193-215

Schneider T (2001) Analysis of incomplete climate data: Estimation of mean values and covariance matrices and imputation of missing values. J Clim 14:853-871

Solíz C, Villalba R, Argollo J, Morales MS, Christie DA, Moya J, Pacajes J (2009) Spatio-temporal variations in Polylepis tarapacana radial growth across the Bolivian Altiplano during the 20th century. Palaeogeogr Palaeoclimatol Palaeoecol 281:296-308

Srur AM, Villalba R, Villagra PE, Hertel D (2008) Influences of climatic and $\mathrm{CO}_{2}$ concentration changes on radial growth of Nothofagus pumilio in Patagonia. Revista Chilena De Historia Natural 81:239-256

Stahle DW et al (1998) Experimental dendroclimatic reconstruction of the Southern Oscillation. Bull Am Meteorol Soc 79:21372152

Stenni B, Proposito M, Gragnani R, Flora O, Jouzel J, Falourd S, Frezzotti M (2002) Eight centuries of volcanic signal and climate change at Talos Dome (East Antarctica). J Geophys Res 107:4076

Stine S (1994) Extreme and persistent drought in California and Patagonia during medieval time. Nature 369:546-549

Szeicz JM, Lara A, Díaz S, Aravena JC (2000) Dendrochronological studies of Pilgerodendron uviferum in southern South America. In: Roig F (ed) Dendrochronología en América Latina. Editorial Nacional de Cuyo, Mendoza, pp 245-270

Taulis E (1934) De la distribution des pluies au Chili. Materiaux pour l'étude des calamités 33:3-20 
Thompson LG, Mosley-Thompson E, Henderson KA (2000) Ice-core palaeoclimate records in tropical South America since the Last Glacial Maximum. J Quat Sci 15:377-394

Thompson LG et al (2006) Abrupt tropical climate change: Past and present. Proc Natl Acad Sci USA 103:10536-10543

Van Ommen T. D., Morgan V., Curran M. A. J. (2004), Deglacial and Holocene changes in accumulation at Law Dome, East Antarctica, in Annals of Glaciology, vol 39, 2005, edited, Int Glaciological Soc, Cambridge, pp 359-365

Vargas WM, Naumann G (2008) Impacts of climatic change and low frequency variability in reference series on daily maximum and minimum temperature in southern South America. Reg Environ Chang 8:45-57

Villalba R (1990) Climatic fluctuations in Northern Patagonia during the last 1000 years as inferred from tree-ring records. Quat Res 34:346-360

Villalba R (1994) Tree-ring and glacial evidence for the medieval warm epoch and the little ice-age in southern South-America. Clim Change 26:183-197

Villalba R, Leiva JC, Rubulls S, Suarez J, Lenzano L (1990) Climate, tree-ring, and glacial fluctuations in the Rio Frias Valley, RioNegro, Argentina. Arct Alp Res 22:215-232

Villalba R, Holmes RL, Boninsegna JA (1992) Spatial patterns of climate and tree growth variations in subtropical Northwestern Argentina. J Biogeogr 19:631-649

Villalba R, Boninsegna JA, Veblen TT, Schmelter A, Rubulis S (1997a) Recent trends in tree-ring records from high elevation sites in the Andes of northern Patagonia. Clim Change 36:425-454

Villalba R, Cook ER, Darrigo RD, Jacoby GC, Jones PD, Salinger MJ, Palmer J (1997b) Sea-level pressure variability around
Antarctica since AD 1750 inferred from subantarctic tree-ring records. Clim Dyn 13:375-390

Villalba $\mathrm{R}$ et al (2003) Large-scale temperature changes across the southern Andes: 20th-century variations in the context of the past 400 years. Clim Change 59:177-232

Villalba R, Grosjean M, Kiefer T (2009) Long-term multi-proxy climate reconstructions and dynamics in South America (LOTRED-SA): state of the art and perspectives. Palaeogeogr Palaeoclimatol Palaeoecol 281:175-179

Vimeux F, Ginot P, Schwikowski M, Vuille M, Hoffmann G, Thompson LG, Schotterer U (2009) Climate variability during the last 1000 years inferred from Andean ice cores: a review of methodology and recent results. Palaeogeogr Palaeoclimatol Palaeoecol 281:229-241

von Gunten L, Grosjean M, Rein B, Urrutia R, Appleby P (2009) A quantitative high-resolution summer temperature reconstruction based on sedimentary pigments from Laguna Aculeo, Central Chile, back to AD 850. Holocene 19:873-881

von Storch H, Zorita E, Jones JM, Dimitriev Y, Gonzalez-Rouco F, Tett SFB (2004) Reconstructing past climate from noisy data. Science 306:679-682

von Storch H, Zorita E, Gonzalez-Rouco F (2009) Assessment of three temperature reconstruction methods in the virtual reality of a climate simulation. Int J Earth Sci 98:67-82

Wanner $\mathrm{H}$ et al (2008) Mid- to Late Holocene climate change: an overview. Quat Sci Rev 27:1791-1828

Xoplaki E, Luterbacher J, Paeth H, Dietrich D, Steiner N, Grosjean M, Wanner H (2005) European spring and autumn temperature variability and change of extremes over the last half millennium. Geophys Res Lett 32:L15713 